\title{
IMPROVEMENT OF STUDENT LEARNING RESULT USING STRATEGY ACCELERATED LEARNING THROUGH VAK APPROACH
}

\author{
Tri Astari \\ STKIP Citra Bangsa, Aceh Utara, Panton Labu \\ Jl. Medan-Banda Aceh Ds Cempeudak. Kec. Tanah Jambo Aye Kab. Aceh Utara, Panton Labu \\ triastari55@gmail.com
}

\begin{abstract}
The root of the problem in this research is the teacher is not successful in conveying the concept to the students, the teacher uses the inappropriate teaching strategies, the low ability of students in the field of mathematics study, students have difficulty in learning math lesson so that student learning outcomes are still low. The purpose of this study is to determine the student activity at the time of learning and student learning outcomes by using the Accelerated Learning Strategy Through VAK Approach. The type of research is Classroom Action Research (CAR). Subjects in this study were students VII-1 SMP PAB Helvetia Medan while the object in this research is Accelerated Learning Strategy Through VAK Approach. The instruments used to consist of observation sheets and learning result tests. This research procedure consists of two cycles, and each period was held twice a meeting. The results showed that: (1) learning activities took place both based on the results of student observations that increased cycle I of $62.50 \%$ and on the second cycle of $87.50 \%$; (2) result of student learning increase based on an initial test there are 23 people $(52.27 \%)$ from 44 students while in cycle I there are 30 people $(68.18 \%)$ and cycle II there are 39 people $(88.63 \%)$ - increased student learning outcomes by $15.91 \%$ classical in the first test to cycle I and $20.45 \%$ from the period I to period II.
\end{abstract}

Keywords: Accelerated Learning Strategy Through VAK Approach, learning outcomes.

\section{PRELIMINARY}

\section{Background}

Mathematics, as an essential subject in school, is the basic science that underlies other science. Mathematics grows and develops independently of other sciences. But the development of mathematics can influence the development of other sciences. With the development of technology, many branches of pure mathematics that turned out to apply in later science and advanced technology.

It also became one of the underlying reasons why everyone must study mathematics because it aims to human knowledge and analyzes what is in nature and its processes as part of the development of science and technology itself. However, mathematics is still a scourge for some people. The evidenced from the even low student learning outcomes in mathematics subjects compared with the value of other items in school. Many factors lead to low learning 
outcomes, one of which is the lack of interest students receive lessons given by teachers. Moreover, mathematics is considered severe.

So is the case with the fractional subject, although it has taught in the seventh grade of junior high school, there are still many high school students who do not understand about the concept of fractions when the idea used on other materials. The is because the concept is not embedded correctly and the lack of understanding of students about the concept, whereas mathematics, is a continuous lesson or continuous between the previous material with the material to be studied next. So this will be difficult if students use the method of memorization into fractions. So students accept the concept like consuming without any feedback that can make the students keep remembering the idea. For that teacher must be able to explain and give a concrete example not abstract to the student. Teachers should also be able to create a design as attractive as possible so as not to cause saturation in students, which ultimately can improve student learning outcomes.

They're realizing, needs to be a renewal in learning to enable students to learn math easier, faster, more meaningful, useful, and fun. One of them is by applying accelerated learning strategy through VAK approach. In accelerated learning strategies students are taught to understand "how to learn" and "how to think," to do activity-based learning and to utilize the senses as much as possible through a 3-stage approach also known as VAK, which stands for Visual (learning through seeing something), Auditory (learning through hearing something), and Kinetics (learning through physical activity and direct involvement).

Therefore, the authors are interested in researching SMP PAB 2 Helvetia Medan through VAK approach, in improving the results of mathematics learning students SMP PAB 2 Helvetia Medan previously low. Based on the above description, the researchers are interested in researching Efforts to Improve Student Learning Results Using Accelerated Learning Strategies Through VAK Approach.

\section{Formulation Of The Problem}

The wording of the problem in this research are:

1. How is the student activity on learning Mathematics on the subject of Fraction by using Accelerated Learning strategy through VAK approach?

2. Does using the Accelerated Learning strategy through the VAK approach improve students' mathematics learning outcomes on the subject of Fractions? 


\section{Literature Review}

\section{Accelerated Learning Strategies Through VAK Approach}

Many similarities between Accelerated Learning (AL), Experiential Learning (EL), and Quantum Learning (QL). These three approaches were born from the psychological and educational revolutions in America and Europe. Accelerated Learning, Experiential Learning, and Quantum Learning are siblings of one mother. His mother is humanistic psychology.

Accelerated learning is a natural way of learning, its roots ingrained since ancient times, and have been done by every child born. Learning Accelererated reborn as a movement to break learning how to learn in the education and training of Western culture in the mid-20th century accelerated the birth Early learning pioneered by a Bulgarian psychiatrist named Dr. Georgia Lazanov in mid-1971. A brief history of Accelerated Learning based on the Lazanov method of calming psychiatric patients by providing music and positive suggestions about their recovery. This method then experiments within learning; it found that the combination of positive music and idea and children's play allows learners to learn far, faster, and far more effectively.

Learning aka accelerated learning is a quick learning strategy to remember/quickly can be a lot, is a way of learning using creative rather than consume. The goal of accelerated learning is to engage learners' learning abilities fully, to make learning fun and rewarding for them, and to contribute wholly to happiness, intelligence, competence, and success. In accelerated learning is the result achieved, not the method used. The is by the statement of Dave Meier (2002:37) that "Any method that can accelerate and improve learning included in the accelerated learning strategy." Thus it can be said that the accelerated learning strategy is an effort to improve the quality of education, especially in learning ability so that it can learn faster, remember more, memorize fast, read quickly, record effective, and creative thinking. Through the application of accelerated learning in the classroom, students who have a weak ability to understand the lesson will look better than before, which likened to the seeds that are about to grow. The basic principles of Accelerated Learning, namely:

1. Learning involves the whole mind and body.

2. Learning is creative, not consuming.

3. Cooperation helps the learning process.

4. Learning takes place at many levels simultaneously.

5. Knowledge comes from doing the work itself (with feedback). 
6. Positive emotions much help to learn.

7. Brain-image absorbs information directly and automatically.

The concept of Accelerated Learning using Visual, Auditory, and Kinesthetic approach abbreviated as VAK. Visual meant as learning through seeing things, Auditory is learning through hearing something, and Kinetics defined as learning through physical activity and direct involvement. According to experts, neurolinguistic Michael Grinder, author of Righting the Educational Conveyor Belt in Bobbi DePorter \& Mike Hernacki (2008:112) states that "In the first group of thirty students, about twenty people are able to learn quite effectively by means of visual, auditory, and kinetic so they do not need special attention". The shows that learning accelerated learning through the VAK approach can help students better understand the material that will be taught, and of course, the knowledge will feel more enjoyable and more meaningful for students. As Khoiruddin opinion Bashori (http://mediadiknas.go.id/medical docs/5406.pdf), accessed January 2009, which states "If the three approaches to learning integrated such that students and teachers can together turn on the atmosphere of the class, so the level with this approach is no longer like a grave, but it is a fun playground for children. The exciting atmosphere is instrumental, not only for student achievement but also reduce stress, improve interpersonal and creativity of students ".

With this three-step approach, when it has implemented maximally, assessed to motivate to learn and improve the results of good learning to engage most students in the class will get the best out of the teaching. Teachers continue with strengthening activities, for example, by assigning tasks to students to retell or teach their friends who have not succeeded, or through quizzes, and others. Whatever subjects, classroom conditions, learning styles, and student abilities, this approach can be applied and will become a standard part of learning planning. The elements of the VAK Approach in Accelerated Learning as follows:

1. Visual (Learning through seeing something)

Visual acuity, though more pronounced in some people, is dominant in everyone, the reason being that in the brain, more devices process visual information than all other senses. Like the primitive human cave paintings and ancient Egyptian hieroglyphs. Submitted to their style, most children sketch and paint when they want to present new ideas through their visual senses. Nancy Margulies, author of Mapping Inner Space and Yes, You Can Draw in Colin Rose and Malcolm 
J. Nicholl (2008: 137) that "Before we learn the language, we visualize images in our minds and relate them to concepts."

2. Auditory (Learning through hearing something)

According to Dave Meier (2002: 95) states that "Our auditory mind is stronger than we realize." Auditory learning is a standard way of learning for all societies since the beginning of history, in line with the philosophy of the ancient Greeks in Dave Meier (2002: 95) which states that "If you want to learn more about anything, then talk non-stop."

3. Kinetics (Learning through physical activity and direct involvement)

We love to "handle," move, touch, and feel/experience themselves. According to Dave Meier (2002: 92) states that "The body and mind are one, the mind spread throughout the body." So, in essence, the body is the mind, and the mind is the body. Both are a genuinely integrated electrical-chemical-biological system. Here the teacher should be able to create a lesson plan in which invites students to be active in the activities learning. Many things can be done by determining the auditory at the time of learning such as modeling in a process or procedure, physically moving various components in a process/system, modeling a method, order or another set of concepts and so on, where all the learning process can do keep students active. Keep in mind, VAK is an integrated element and carried out continuously in one learning time. The stages of VAK are not a rigid sequence. For example, Students can learn a little by watching a presentation (V), but they can learn far more if they can do something while the performance is going on (K), and talk about what they are learning (A). Or, students can improve their ability simultaneously by moving something or describing something $(\mathrm{K})$, to produce a concept picture (V), and while discussing what they are doing (A).

\section{Learning Outcomes}

Learning outcomes are indicators for measuring student success in the learning process. Learning outcomes are the abilities that students get after teaching activities. From the student side, the learning outcomes are the peak of the learning process, which is proof of the effort that has done. According to Hamalik (2010:23) affirms "that learning outcomes appear as an occurrence of behavioral changes in students, which can be observed and measured in changes in knowledge, attitudes, and skills." Changes can mean better upgrades and development than ever before, for example, from being ignorant, being polite, and being polite, and so on. The same thing is put forward by Supardi (2015:2) that "learning outcomes are actual achievement stages 
that displayed in the form of behavior that includes cognitive, affective, and psychomotor aspects and can see in the form of habits, attitudes, and rewards."

Subsequently, Sudjana (in Kunandar, 2008:276) states that "learning outcomes are a result of the learning process by using measurement tools, i.e., in the form of well-planned tests, whether written tests, oral tests or action tests." While S.Nasution (in Kunandar, 2008:276) argues that "learning outcomes are a change in the learning individual, not just about knowledge but also shaping the skills and self-awareness in the individual of the learning individual." Another opinion put forward by Fudyartanto (2002:23) that "learning outcomes are the mastery of knowledge and several new skills and new attitudes, or strengthening something that has been mastered before, including understanding and mastery of values."

From the above understanding, it can be concluded that the learning outcome is the ability obtained by students after gaining experience learning so that it can construct knowledge in everyday life. The process of assessment of learning outcomes can provide information to teachers about the progress of students to achieve learning objectives through learning activities. Furthermore, from the data, the teacher can arrange and foster student activities further, both the whole class and individual. Learning outcomes are the final result of decision making about the high value obtained by the students during the learning process. Learning outcomes are said to be high if the level of student ability increases from previous results.

\section{RESEARCH METHODS}

\section{Research sites}

The location of the research conducted at SMP PAB 2 Helvetia Medan J1. Veteran Pasar 4 Helvetia.

\section{Population and Sample}

The community in this study there are 4 (four) classes, amounting to 170 students. For the sample of the researcher only takes 1 (one) level of 44 people.

\section{Types and Research Approach}

This type of research is Classroom Action Research (PTK) or Classroom Action Research. The approach used is a qualitative approach that is useful for expressing students' learning difficulties in learning the material and how to overcome it as an effort to improve the reasoning of the concept of the content to enhance student learning outcomes. 


\section{Research Procedure}

The procedure of conducting classroom action research, according to Zainal Aqib (2006:127) can be described as follows:

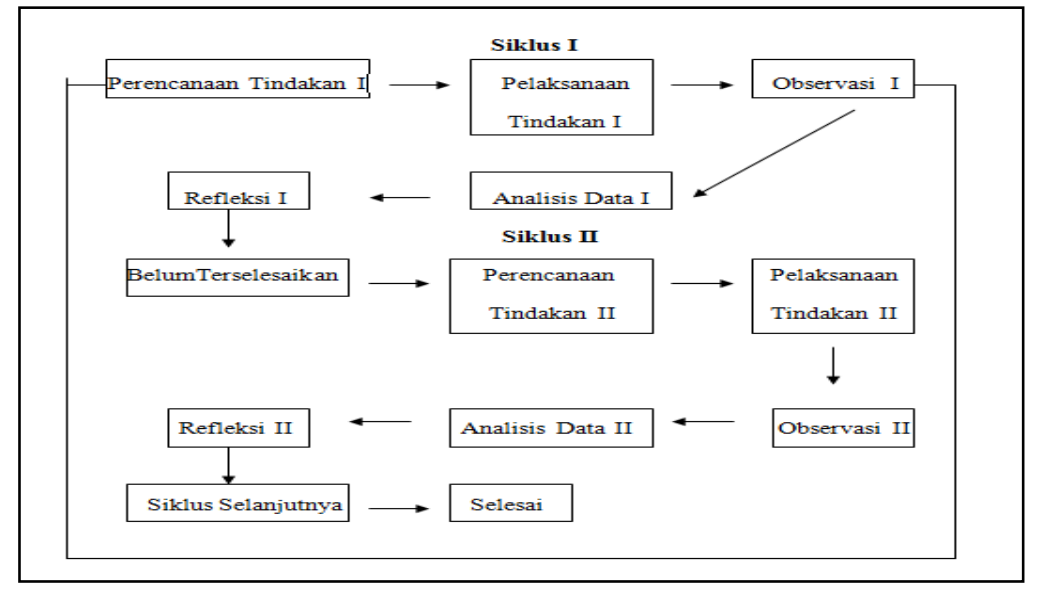

Figure 1. Implementation Procedure Research

\section{DISCUSSION OF RESEARCH RESULTS}

This study was conducted to know the student activity at the time of learning and to know the student learning outcomes by using Accelerated Learning Strategies Through VAK Approach on the subject of Fractional. The cause of low student learning outcomes on the subject of Fraction is the lack of mastery over the concept of Fractional. Also, the seventh- or thirteen-year-old junior high school students, according to Piaget's theory of learning in Anton Lubis (2006:36) state that "some of them are still in solid operation phase, some are entering formal operations and others in transition between specific operations and legal operations." Consequently many of their intellectual developments have not yet reached the point of mental structure required for official mathematical evidence, children at this stage have difficulty in understanding oral abstraction so that teachers should be able to demonstrate tangible things that can then visualized in the delivery of concepts to students. To overcome this, then the teaching using the Accelerated Learning Strategy Through VAK Approach.

Based on the results of data analysis can be concluded that the student activity in the learning process in the first cycle reached $62.50 \%$ and in the second cycle increased to $87.50 \%$. During the learning process took place look enthusiastic students to be more active in learning math. Learning by using accelerated learning strategy through VAK approach was able to improve student learning outcomes on the subject of Fractional. Students' mastery of learning 
materials has increased. The can be demonstrated by the level of completeness of the evaluation results of students in the classical before the implementation of accelerated learning strategy through VAK approach obtained 23 people $(52.27 \%)$ who have reached the level of mastery learning, while 14 people $(31.82 \%)$ has not reached the level of mastery learning and after the implementation of accelerated learning strategy through VAK approach has increased in cycle I through the test result I obtained 30 people $(68.18 \%)$ who have reached the level of mastery learning, while 14 people $(31.82 \%)$ has not reached the level of mastery learning. While the result of student learning in cycle II through test result of learning II obtained 39 people $(88.63 \%)$, who have reached the level of mastery learning, while 5 people $(11.36 \%)$ have not reached the level of mastery learning. Means an increase of $15.91 \%$ in the first test to cycle I and $20.45 \%$ of the cycle I cycle II. Thus it can be said that Accelerated Learning Strategy Through VAK Approach is a strategy that can improve student activity and learning outcomes. Especially in the ability to learn faster, remember more, memorize fast, read soon, record effective, and creative thinking. Through the application of accelerated learning in class, students who have a weak ability to understand the lesson will look better than before, which likened to a seed that is about to grow.

\section{CONCLUSION}

Based on the data and the results of the analysis that has presented can be concluded that the student activity in the learning process in the first cycle reached $62.50 \%$ and in the second cycle increased to $87.50 \%$. During the learning process took place look enthusiastic students to be more active in learning math. In addition, the results of student learning increased using the Accelerated Learning strategy Through VAK Approach where the effects of knowledge based on the initial test there are 23 people $(52.27 \%)$ of 44 students while in the first cycle there are 30 people $(68.18 \%)$ and cycle II there were 39 people $(88.63 \%)$. Increased student learning outcomes by $15.91 \%$ classical in the first test to cycle I and $20.45 \%$ from cycle I to cycle II.

\section{SUGGESTION}

Based on the results of this study, researchers put forward some ideas that in teaching teachers need to pay attention to strategies or new approaches so that the teaching is not monotonous. Therefore, students do not feel bored and regard mathematics as a painful lesson. 
From the results of the study found that most students do not dare to ask opinions or questions about things that have not been understood directly to the teacher when the learning process takes place, it is advisable to teachers who will implement this strategy is expected to learn how to motivate students to speak and ask courage.

\section{BIBLIOGRAPHY}

Aqib, Zainal. 2006. PTK For Teachers. Bandung: Yrama Widya.

Bashori, Khoiruddin. Class Not Grave. http://mediadiknas.go.id/medical document/5406.pdf/. Accessed January 2009.

DePorter, Bobbi \& Mike Hernacki. 2008. Quantum Learning: Familiarize the Learning Convenient and Fun. Bandung: Kaifa.

Hamalik, Oemar. (2010). Teaching and learning process. Bandung: Earth Literacy.

Kunandar. 2008. Easy Step Classroom Action Research As Teacher Profession Development. Jakarta: Rajawali Press.

Lubis, Anton. 2006. Learning Strategies and Models. Jakarta: Kencana.

Meir, Dave. 2002. The Accelerated Learning Handbook: Creative and Effective Guidelines Designing Education and Training Programs. Bandung: Muslich, Masnur. 2009. Implementing TOD Easy (Classroom Action Research). Jakarta: PT. Earth Script.

Nurhasni. Accelerated Learning Approach to VAK. http://nurhasniblogkuyess.blogspot.com/2008/AcceleratedLearning Accessed January 2009. Rose, Colin, and Malcolm J. Nicholl. 2008. Accelerated Learning for 21st Century (How to Learn Fast XXI Century). Bandung: Nuance.

Sudjana, Nana. 2005. Research Results Learning. Bandung: Rosda Karya. 